\title{
DAMPAK KEBAKARAN HUTAN GAMBUT TERHADAP SUBSIDENSI DI HUTAN TANAMAN INDUSTRI
}

\author{
Ambar Tri Ratnaningsih, Sri Rahayu Prastyaningsih \\ Staff Pengajar Fakutas Kehutanan Universitas Lancang Kuning \\ JIn. Yos Sudarso Km. 8 Rumbai Pekanbaru Riau \\ Email: ambar_trn@yahoo.com dan srirahayu_pn@yahoo.co.id
}

\begin{abstract}
Forest fires in peat soils will affect hydrological characteristics and hydrological cycles. Industrial Plantation Forest in Riau Province is mostly located in peat soil. This study aims to measure the impact of forest fires on peat subsidence and water table level. The research location is located in industrial forest plantation located in Bengkalis Regency, Riau Province. The method of research is to install piezometer and iron rod stuck into the soil to penetrate the mineral soil layer, then the iron that appears on the surface of the soil is made permanent sign for reference in monitoring the altitude change of the surrounding surface (subsidency). The fire peat forest has a depth of $12.21 \mathrm{~cm}$ month $^{-1}$ down water level from the peat surface while in the unburned area $10 \mathrm{~cm}$ month $^{-1}$. In the burnt area the rate of peat surface decline is $0.159 \mathrm{~cm} \mathrm{month}^{-1}$ while the unburned area is $0.119 \mathrm{~cm}$ month-1
\end{abstract}

Keywords: subsidence, water table level, industrial tree plantations, forest fires

\section{PENDAHULUAN}

Menurut Jikalahari, Provinsi Riau merupakan wilayah yang memiliki gambut yang terluas di Sumatera 4,044 juta hektar $(56,1 \%$ dari luasan lahan gambut Sumatera atau $45 \%$ dari luas daratan Provinsi Riau). Lahan gambut merupakan salah satu ekosistem multi fungsi sebagai pelindung fungsi hidrologi, sumber keanekaragaman hayati, pangan dan energi dan pengendali ilkim global Hooijer et /al., 2010, dan Hirano., 2014). Lahan gambut di Provinsi Riau terancam keberadaannya mengingat keinginan pemerintah menjadi produsen pulp dan kertas nomor 5 di dunia.
Salah satu upaya yang dilakukan untuk mendukung rencana tersebut, pemerintah telah mengalokasikan lahan seluas 15 juta ha untuk Hutan Tanaman Industri (HTI) sampai tahun 2015. Permasalahan HTI di lahan gambut adalah drainase, penurunan permukaan gambut (subsidensi) dan banjir, kebakaran, pencemaran udara dan emisi $\mathrm{CO}_{2}$.

Kebakaran hutan dan lahan gambut di Provinsi Riau terjadi sejak tahun 1997 dan berulang setiap tahunnya sampai saat ini. Menurut Eyes on The Forest dalam Mongabay (2014) menyebutkan bahwa pada bulan Maret 2014 terdapat 8,487 titik api. Kebakaran hutan diperkirakan 
menyumbangkan emisi $\mathrm{CO}_{2}$ yang cukup besar kontribusinya baik dalam level nasional, regional dan internasional. Provinsi Riau dengan kontribusi lahan gambut $45 \%$ di Indonesia dimana sebagian besar diperuntukkan untuk Hutan Tanaman Industri ( $\mathrm{HTI})$, pada saat ini kondisinya terancam. Data hot spot dari 5 tahun terakhir memperlihatkan sumber kebakaran hutan dan lahan di Riau sudah bergeser dari lahan mineral ke lahan gambut. Menurut data konsesi yang ada di Indonesia, menunjukkan bahwa masingmasing $27 \%$ dari luas area konsesi untuk kelapa sawit dan HTI berada pada lahan gambut, dengan rinciannya adalah 28.009 $\mathrm{km}^{2}$ untuk perkebunan kelapa sawit dan $19.923 \mathrm{~km}^{2}$ untuk HTI (Hooijer et al., 2006).

Lahan gambut yang terlantar akibat kebakaran sehingga tidak bisa ditanami memiliki permukaan lahan yang tidak rata. Topografi lahan juga dipengaruhi oleh besarnya penurunan muka tanah dari gambut akibat kebakaran dan intensifikasi pengelolaan. Dradjat et al. (1986) diacu dalam Rina et al. (2008) melaporkan laju penurunan muka tanah dalam 1 bulan mencapai 0,36 cm selama 12-21 bulan setelah reklamasi di Barambai (Kalimantan Selatan). Sedangkan untuk gambut saprik di Talio (Kalimantan Tengah) laju subsiden setiap bulan mencapai $0,178 \mathrm{~cm}$ dan gambut hemik $0,9 \mathrm{~cm}$ bulan. Demikian juga pada lokasi yang sama penurunan muka tanah di Desa Babat Raya dan Kolam Kanan Kecamatan Barambai Kalimantan Selatan mencapai antara 75$100 \mathrm{~cm}$ dalam masa 18 tahun (April 1978 September 1996) (Noorginayuwati et al.1996 diacu dalam Rina et al. 2008). Terjadinya penurunan muka tanah disebabkan oleh pengeringan yang berlebihan, kebakaran atau pembakaran, intensifikasi pemanfaatan dan upaya konservasi yang kurang memadai. Oleh karena itu untuk pemanfaatan lahan gambut perlu disesuaikan dengan tipe hidrologi lahan gambut.

Sifat inheren gambut yang penting adalah sangat sensitif terhadap perubahan lingkungan. Menurut Sarwono (2003) sifat inheren gambut tropika yang kurang menguntungkan diantaranya adalah kering tidak balik (irreversible drying) dan penurunan (subsidence). Apabila mengalami pengeringan yang berlebihan koloid gambut menjadi rusak sehingga terjadi gejala kering tidak balik dan gambut berubah sifat seperti arang sehingga tidak mampu lagi menyerap hara dan menahan air sehingga membuatnya peka tererosi. Lebih lanjut dijelaskan oleh Sarwono (2003) bahwa gambut akan kehilangan air tersedia setelah 4-5 minggu mengalami pengeringan, kondisi ini menyebabkan gambut mudah terbakar. Tanah gambut juga memiliki sifat penurunan permukaan 
tanah yang besar setelah dilakukan drainase

Penelitian bertujuan untuk mengukur pengaruh kebakaran hutan terhadap subsidensi gambut dan tingi muka air tanah (water table level).

\section{METODE PENELITIAN}

Penelitian dilakukan pada bulan April sampai Juli 2016 di HTI yang secara administrasi pemerintahan terletak di Desa Sukajadi Kecamatan Bukit Batu, Kabupaten Bengkalis, Provinsi Riau. Secara umum topografi berupa rawa-rawa tergenang periodik (gambut) dengan topografi datar. Areal berada pada ketinggian kisaran $0-15 \mathrm{~m}$ di atas permukaan laut, masuk dalam kategori dibawah $100 \mathrm{~m}$, yang mencerminkan landainya topografi areal tersebut. Lokasi penelitian termasuk dalam kategori lahan basah yang memiliki karakteristik Hutan Rawa Gambut. Kedalaman gambut terbagi atas 3 nilai yaitu, I) tanah gambut dengan kedalaman kurang dari $3 \mathrm{~m}$, II) memiliki kedalaman gambut antara 3-6 m dan nilai III) yang mempunyai kedalaman diatas 6 m. Profil tingkat kematangan gambut (dekomposisi bahan organik) dari permukaan tanah $(0-50 \mathrm{~cm}), 50-100 \mathrm{~cm}$ dan diatas $100 \mathrm{~cm}$ dengan kombinasi dari 3 kelas hemik, saprik dan fibrik. Berdasarkan sistem klasifikasi iklim Schmidt and Ferguson, lokasi penelitian termasuk kedalam tipe iklim sangat basah (Tipe $A$, nilai $Q: 0,11-0,12$ ), dan tipe tropika basah (Af) berdasarkan Koppen (1951). Data iklim 10 tahunan (1990-1999) menunjukkan kondisi iklimnya adalah curah hujan cukup tinggi (rata-rata 1.890,6 $\mathrm{mm} / \mathrm{thn}$ ) dengan hari hujan rata-rata tahunan sebesar 129,2 hari/tahun. Kecepatan angin rata-rata bulanan berkisar antara 5,6 - 6,6 knot.

Pengukuran subsidensi dan tinggi muka air tanah dilakukan pada areal bekas kebakaran dan tidak terbakar. Pengambilan data pada masing-masing dilakukan dalam satu transek yang dibuat tegak lurus dengan saluran drainase. Pada areal yang terbakar dibuat beberapa titik pengamatan dengan pendekatan penentuan titik pengamatan menggunakan sistem transek yaitu terrain technique berdasarkan keadaan fisiografi lahan yang memberikan pola perubahan sifat lahan. Jarak antara satu titik dengan titik lain dalam setiap transek adalah 300 m dengan kedalaman gambut 6-8 meter, sedangkan jarak antar transek $1000 \mathrm{~m}$. Pada areal bekas kebakaran dibuat dua transek yaitu A dan B. Sedangkan pada areal yang tidak terbakar dibuat dua transek yaitu $C$ dan $D$. Pada setiap transek dibuat 3 titik pengamatan.

Pada masing-masing titik pengamatan dilapangan diamati subsidensi dan tinggi muka air tanah. 
Untuk monitoring tinggi muka air tanah pada masing-masing titik pengamatan dipasang piezometer dari pipa paralon berdiamater 1 inci yang dibenamkan secara vertikal kedalam tanah. Pada masing-masing lokasi pengamatan juga dipasang tongkat dari besi yang ditancap ke dalam tanah sampai menembus lapisan tanah mineral, kemudian pada besi yang muncul di permukan tanah dibuat tanda permanen untuk acuan dalam monitoring perubahan ketinggian permukaan tanah (subsidensi) disekitarnya.

\section{HASIL DAN PEMBAHASAN}

Pemanfaatan lahan gambut untuk Hutan Tanaman Industri diawali dengan pembuatan saluran drainase dan pembukaan lahan yang kemudian dilanjutkan dengan penyiapan lahan untuk penanaman. Drainase merupakan prasyarat dalam pemanfaatan lahan gambut yaitu pertama untuk membuang kelebihan air dan hujan secara tepat waktu dan efesien dan yang kedua untuk pengendalian muka air tanah agar tercapai kondisi yang optimum untuk pertumbuhan tanaman. Jumlah air yang yang harus dilimpahkan dari suatu lahan didasarkan pada kebutuhan tanaman untuk pertumbuhan dan produksinya yang optimum. Ukuran drainase disesuaikan dengan jumlah air yang yang akan dibuang melalui saluran drainase sehingga memenuhi jumlah air yang diinginkan untuk tanaman.

Subsiden atau penurunan permukaan lahan merupakan kondisi fisik yang sering dialami lahan gambut yang telah didrainase. Proses drainase menyebabkan air yang berada diantara massa gambut mengalir keluar, akibat proses ini gambut mengempis atau mengalami penyusutan. Subsiden juga bisa terjadi akibat massa gambut mengalami pengerutan akibat berkurangnya air yang terkandung dalam bahan gambut. Proses lainnya yang menyebabkan penurunan permukaan gambut adalah proses pelapukan (dekomposisi). Drainase menyebabkan perubahan kondisi gambut dari anerob (miskin oksigen) menjadi aerob (kaya oksigen) sehingga mikroba pembusuk (dekomposer) menjadi lebih aktif yang mengakibatkan terjadinya penurunan fungsi gambut sebagai penyimpan karbon dan berkontribusi terhadap peningkatan konsentrasi gas rumah kaca di atmosfer.

Pengamatan subsiden pada areal bekas kebakaran dan tidak terbakar dilakukan selama 4 bulan. Data pengamatan disajikan pada tabel 1 . 
Tabel 1. Titik Batas Turunnya Permukaan Air (Water Table level) pada Lahan Gambut Bekas Kebakaran dan Tidak Terbakar

\begin{tabular}{|c|c|c|c|c|}
\hline Lokasi & $\begin{array}{l}\text { Titik } \\
\text { Penga } \\
\text { mbilan } \\
\text { Sampel }\end{array}$ & $\begin{array}{l}\text { Water } \\
\text { Tabel } \\
\text { Bulan } \\
\text { Juni } \\
\text { (cm) }\end{array}$ & $\begin{array}{l}\text { Water } \\
\text { Tabel } \\
\text { Bulan } \\
\text { Oktobe } \\
\text { r (cm) }\end{array}$ & $\begin{array}{l}\text { Rata- } \\
\text { rata } \\
\text { Water } \\
\text { Tabel } \\
\text { per } \\
\text { bulan } \\
\text { (cm) }\end{array}$ \\
\hline \multirow{4}{*}{$\begin{array}{c}\text { Bekas } \\
\text { Kebakara } \\
\text { n }\end{array}$} & 1 & 49,8 & 102,2 & 13,1 \\
\hline & 2 & 40,5 & 92,9 & 13,1 \\
\hline & 3 & 31,3 & 83,7 & 13,1 \\
\hline & 4 & 32,6 & 70,7 & 9,52 \\
\hline \multicolumn{2}{|c|}{ Rata-rata } & 38,55 & 87,38 & 12,21 \\
\hline \multirow{4}{*}{$\begin{array}{c}\text { Tidak } \\
\text { Terbakar }\end{array}$} & 1 & 92,2 & 137,4 & 11,3 \\
\hline & 2 & 52,1 & 97,3 & 11,3 \\
\hline & 3 & 64,4 & 103,3 & 9,72 \\
\hline & 4 & 61,1 & 91,8 & 7,68 \\
\hline \multicolumn{2}{|c|}{ Rata-rata } & 67,45 & 107,45 & 10 \\
\hline
\end{tabular}

Berdasarkan tabel 1 dapat dikethui bahwa hutan gambut bekas kebakaran memiliki titik kedalaman turunnya muka air (water tabel) sebesar 12,21 cm/bulan dari permukaan gambut sedangkan pada areal tidak terbakar sebesar $10 \mathrm{~cm} /$ bulan. Semakin dalam titik turunnya permukaan air menyebabkan kadar air yang terkandung pada permukan lahan gambut semakin berkurang, sehingga gambut permukaan menjadi kering. Kondisi ini mengakibatkan apabila terjadi kebakaran akan semakin besar kemungkinan merambatnya api kedalam lapisan gambut. Pembangunan kanal bertujuan mengalirkan air tanah gambut sehingga gambut permukaan menjadi kering dan dapat diolah untuk menanam tanaman. Hal ini menyebabkan gambut kehilangan fungsi hidrologis, besarnya nilai bulk density di permukaan dan menyebabkan permukan gambut itu kering yang mengakibatkan tingginya sensivitas gambut permukaan terhadap api terutama pada saat musim kemarau. Dengan demikian pada areal bekas kebakaran memiliki ancaman atau resiko kebakaran hutan lebih tinggi jika dibandingkan dengan areal yang tidak terbakar.

Kedalaman turunnya permukaan air dari permukaan gambut sangat berpengaruh dengan karakteristik permukaan lahan gambut. Penurunan muka air tanah yang terjadi menyebabkan terjadinya penurunan karakteristik kimia air tanah yang menyebabkan terjadinya penurunan karakteristik kimia pada lapisan diatas muka air atau pada gambut permukaan yang mengalami subsiden antara lain meningkatnya kadar $\mathrm{N}$ dan penurunan kadar $\mathrm{C}$ akibar proses terjadinya proses oksidasi bahan organic yang lebih besar pada lapisan di atas muka air tanah. Rata-rata kandungan $\mathrm{N}$ cenderung lebih tinggi pad lapisan di atas muka air tanah dimana terjadi tingkat dekomposisi yang lebih besar dan aktivitas perkaran serta mikroorganisme yang cukup intensif pada lapisan ini. Kadarnya cenderung lebih rendah pada lapisan di 
bawah muka air tanah. Tingginya muka air berpengaruh terhadap jumlah $\mathrm{N}$ yang dilepaskan, karena mempengaruhi zona perakaran, aerasi dan temperature. Semakin tinggi muka air, jumlah $\mathrm{N}$ yang tersedia bagi tanaman semakin rendah.

Penurunan permukaan lapisan gambut (subsidence) berkolerasi positif dengan penurunan muka air. Laju subsiden untuk tiga kali pengamatan di areal bekas kebakaran dan tidah terbakar di lokasi penelitian dapat dilihat pada gambar 1

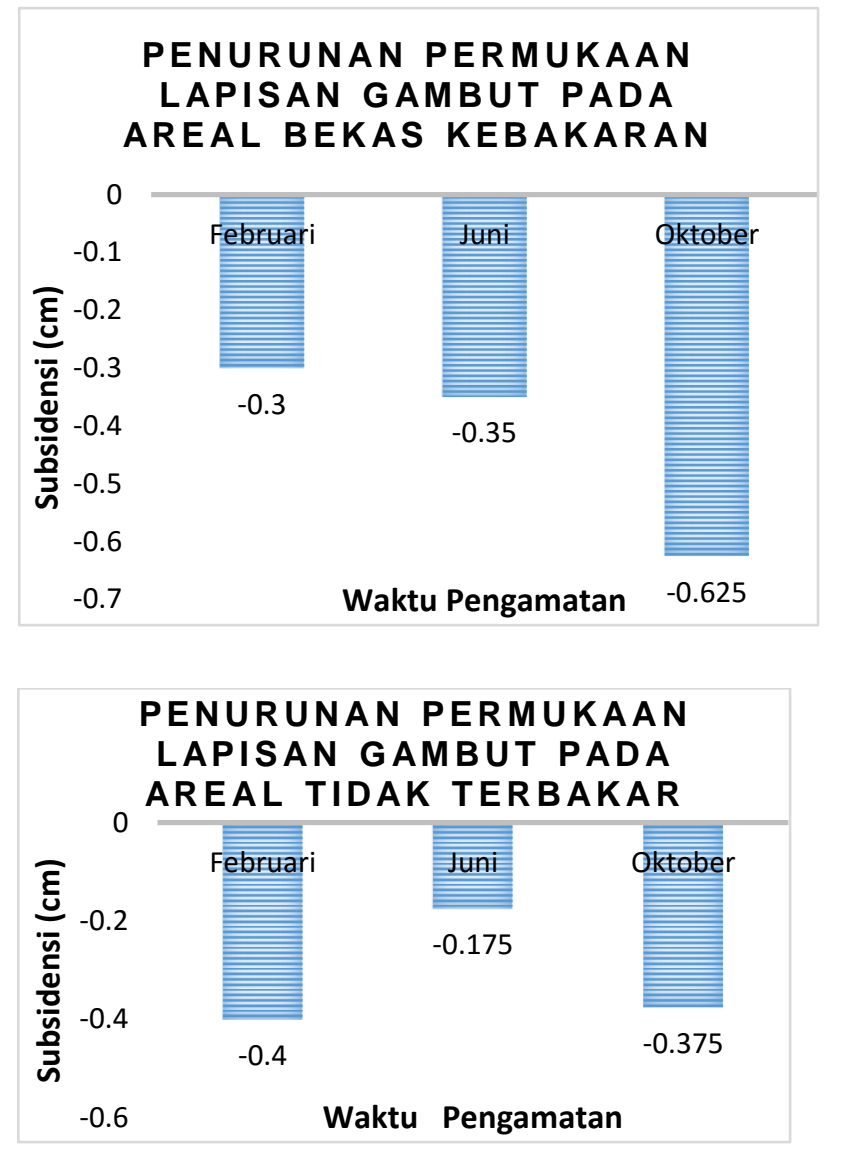

Gambar 1. Penurunan Permukaan Lapisan Gambut pada Areal Bekas Kebakaran dan Tidak Terbakar

Berdasarkan gambar 1 diketahui pada areal bekas kebakaran laju penurunan permukaan gambut sebesar $0,159 \mathrm{~cm} / \mathrm{bula}$, sedangkan pada areal tidak terbakar sebesar $0,119 \mathrm{~cm} /$ bulan. Tingkat penurunan permukaan gambut pada areal bekas kebakaran lebih tinggi dibandingkan dengan areal tidak terbakar. Kebakaran hutan menyebabkan tingginya penurunan muka air tanah sehingga terjadinya pemadatan tanah dan menurunnya kadar air tanah yang berdampak pada tingginya nilai bulk density.

Menurut Maswar, et al (2011) Hasil uji korelasi menunjukkan bahwa kehilangan karbon berkolerasi positif sangat nyata dengan subsiden dan dalam muka air tanah maksimum. Penurunan muka air tanah mengakibatkan perubahan kondisi anerob pada lapisan permukaan tanah yang mengering sehingga menyebabkan dekomposisi material gambut lebih cepat pada lapisan di atas muka air tanah sehingga lebih banyak karbon yang hilang karena terdekomposisi. Kebutuhan akan tingginya muka air tanah akan berbeda tergantung jenis tanaman yang ditanam. Tinggi muka air yang optimal bervariasi seiring dengan kedalam dari zona perakaran, fase pertumbuhan tanaman dan aktifitas pengolahan tanah

\section{KESIMPULAN}

Hutan gambut bekas kebakaran memiliki titik kedalaman turunnya muka air (water table) sebesar 12,21 cm /bulan dari 
permukaan gambut sedangkan pada areal tidak terbakar sebesar $10 \mathrm{~cm}$ per bulan. Semakin dalam titik turunnya permukaan air menyebabkan kadar air yang terkandung pada permukan lahan gambut semakin berkurang, sehingga gambut permukaan menjadi kering dan rentan terbakar. Pada areal bekas kebakaran laju penurunan permukaan gambut sebesar $0,159 \mathrm{~cm} /$ bulan sedangkan pada areal tidak terbakar sebesar $0,119 \mathrm{~cm} /$ bulan..

\section{DAFTAR PUSTAKA}

Hirano T, Kusin K, Limin S dan OskiM., 2014. Carbon Dioxide Emissions Trough Oxidative Peat Decompositon on A Burt Trocical Peatland. Global Cgange Biologi,20(10):555-565.

Hooijer, A., Page, S., Canadell, J.G., Silvius, M., Kwadijk, j., Wosten, $\mathrm{H}$. dn Jauhiainen, J., 2010.Current and Future CO2 Emissions from Drained peadlands in Southeast Asia. Biogeosciences, 7:1-10.

Hooijer, A.M. Silvius, H. Wosten, and S.Page.2006. PEAT CO2, Assessment of $\mathrm{CO}_{2}$ Emission from Drained Peatlands in SE Asia. Wetland Internasional and Delft Hydraulics Report 03943.

Maswar, S., Haridjaja, O., Sabiham, O., dn Van Noordwijk, M., 2011. Cadangan, Kehilangan dan Akumulai Sawit di Lahan Gambut Tropika. Journal of Soil and Land Utilization Managrment, 8(1):1-10.

Mongabay, 2014. WWF: RAPP Harus Hentikan Penghancuran Gambut di Pulau

Padang. http://www.mongabay.co.id/ 2014/06/02/.

Rina,Y., I. Ar-Riza dan M.Noor., 2008. Profil Sosial Ekonomi dan kelembagaan Petani di Lahan Bukan Baru Kasus Desa Petak Batuan, Dadahup A2, Kalteng. Disajikan pada Seminar Nasional Padi, 23-24 Juli 2008 di Sukamandi Balai Besar Penelitian Tanaman Padi. Badan Litbang Pertanian, Deptan.

Sarwono. 2003. Klsifikasi tanah dan Pedogenesis. Akademik Pressindo, Jakaarta 